\title{
A PHYLOGENETIC STUDY ON THE OCCURRENCE AND DISTRIBUTION OF HISTAMINE IN THE GASTRO-INTESTINAL TRACT AND OTHER TISSUES OF MAN AND VARIOUS ANIMLALS*
}

\author{
W. LORENZ, E. MATEJKA, A. SCHMLA, W. SEIDEL, H-J. REIMLANN, \\ R. UHLIG, AND G. MANN'
}

Division of Experimental Surgery and Pathological Biochemistry, Surgery Clinic of the University, Marburg/Lahn, and Institute of Clinical Chemistry and Clinical Biochemistry of the University, Munich, Germany:

(Received I 3 November, 1972)

\begin{abstract}
Using a specific fluorimetric and biological method, the occurrence and distribution of histamine was investigated in man, various mammals, birds, reptiles, amphibians, bony and cartilaginous fishes, lancelets, tunicates, echinoderms, molluscs, and crustaceans. The amine was identified by the fluorescence spectrum, by specific antihistaminies in the bioassay, by the comparison of the fluorimetric histamine values following three different isolation procedures, and in some tissues also by thin-laver chromatography.

Histamine was found in all chordates in considerable concentrations with the exception of the stomachless carp. The distribution of histamine in the body, however, varied largely from species to species. Only the gastric mucosa of all vertebrates investigated was relatively rich in histamine.

The amine was nearly uniformly distributed in amphibians and fishes, in which only the stomach and partly the intestinum showed highèr histamine concentrations than all the numerous other tissues investigated. The distribution of histamine, however, in mammals, birds, and reptiles showed great variations from tissue to tissue. Organs free from histamine were first found in fishes going backward in the phylogeny.

Because of the great variabilities in the distribution of histamine in the body of numerous species which were studied in this investigation, only one hyporhesis can be developed with respect to a common physiological significance of histamine: there is a selective accumulation of histamine in the gastric mucosa of all chordates possessing acidsecreting cells and a low concentration of histamine in the gastro-intestinal tract of stomachless fishes. The gastric acid secretion is stimulated by histamine in all vertebrates investigated, whereas in many fishes histamine has no effects on the circulation or on smooth muscles of the gastro-intestinal tract or on the uterus. Thus, stored histamine probably has a specific function in the gastric mucosa, but not a general function, such as the regulation of ubiquitous metabolic processes or the regulation of microcirculation.
\end{abstract}

INVESTIGATIONS on the occurrence and distribution of histamine in animals have been performed by numerous authors (for a survey see Lorenz and Werle, 1974), since Best, Dale,

* Dedicated to E. Werle for his 70 th birthday.

+ Supported by grants of Deutsche Forschungsgemeinschaft (Lo $199 / 1$, and SFB 37 'Restitution und Substitution innerer Organe').

* Requests for reprints should be sent to $W$. Lorenz, Division of Experimental Surgery and Pathological Biochemistry, Surgery Clinic of the University, D-3550 Marburg/Lahn, Robert-KochStraße 8, Germany.
Dudley, and Thorpe (1927) first demonstrated the existence of this biogenic amine in mammalian tissues by elementary analysis. For several reasons, however, it seems necessary, to determine and reinvestigate the histamine contents in as many tissues and species as possible:-

1. Some methods for the determination of histamine which were used in prior studies, were shown to have a less than satisfactory specificity in body fluids and in certain tissues (Carlini and Green, I g63; Michaelson and Coffman, I 967; Lorenz, Benesch, Barth, 
Matejka, Meyer, Kusche, Hutzel, and Werle I970; Lorenz, Barth, Kusche, Reimann, Schmal, Matejka, Mathias, Hutzel, and Werle, 1971). Thus a reinvestigation about the histamine contents of numerous tissues should be performed with the aid of more specific methods.

2. For several tissues, in which a physiological role of histamine is considered, no or only very few data are available about their histamine concentration. Such tissues are, for instance, the skeletal muscles and the ureter, where histamine may be involved in the functional hyperaemia (Schayer, 1964) or in the spontaneous motility (Borgstedt, Benjamin, and Emmel, I 962). Furthermore, nothing is known about the histamine content of many human tissues.

3. A much greater species variability than expected was found in the distribution and cellular localization of histamine (Hákanson, Owman, Sjöberg, and Sporrong, 1970 ; Lorenz and Werle, 1974). In this respect a comparison of numerous species seemed necessary in order to ind out whether there exist any regularities which may be helpful in studies on the physiological role of histamine in animals.

4. Only few phylogenetic investigations have been performed on the occurrence and distribution of histamine in animal tissues (Ungar, Ungar, and Parrot, r.937; Mettrick and Teiford, 1965; Reite, 1965; Lorenz, Schauer, Heitland, Matejka, and Werle, 1969; Reite, I969a; Takaya, 1969). A comparison of the pharmacological effects of histamine in various phyla and classes of the animal kingdom with its occurrence and distribution in tissues seems to be one way to elucidate physiological functions of histamine. Such functions have been discussed especially frequently in the gastro-intestinal tract which therefore was intensively studied in this investigation.

\section{MATERIALS AND METHODS}

\section{Materials}

Animals and Tissues

The election of species was influenced by several factors, the most important of which were aspects of sysiematic zoology, frequent use of the species in physiological or pharmacological investigations, and the possibility of obtaining fresh tissues immediately after the death of the animais.

With the exception of the human tissues which were collected throughout the whole year, the organs of all other species investigated were prepared during the months September until December, since according to Reite and Davis (1970) seasonal changes of the mast cell density can occur in the tissues. Furthermore, the tissues of the various species were obtained from three different places: those of man, dog, Mastomys, and rabbit from Marburg (central Germany); those of the cartilaginous fishes and of all the species which are lower in the phylogeny than the elasmobranch fishes. from Napies, Italy; ; and those of all the remaining species from Munich (southern Germany).

The human tissues were withdrawn as exploratory excisions during the operations at the Surgery Clinic of Marburg. By microscopical control all tissues were found to be normal and healthy. Histamine release in man by the anaesthetics used (thiopentone, suxamethonium, fluothane, $N_{2} \mathrm{O}$ ) and by the stress during the operation can be considered as minimum (Lorenz, Doenicke, Meyer, Reimann, Kusche, Barth, Geesing. Hutzel, and Weissenbacher, 1972; Seidel, Lorenz, Doenicke. Mann, and Uhlig, 1973). Thus, the argument of Kumar, Laddu, Lahiri, and Sanyal (1968), that the withdrawal of tissues during operations may not guarantee physiological histamine contents, cannot be accepted for our tissue samples.

The organs from pigs (Deutsches veredeltes Landschwein), cattle (Höhenfleckvieh), and sheep (Deutsches schwarzköpfiges Fleischschaf) were obtained in the slaughter-house immediately after the death of the animals; those from the pheasants during the hunt; those from dogs (Deutscher Schäferhund), foxes, miniature pigs (Zucht Hannover), and rabbits (New Zealand) after anaesthesia with pentobarbitone (10-35 mg. per $\mathrm{kg}$. i.v.) and bleeding. The tissues from guinea-pigs (laboratory strain), rats (Wistar), and Mastomys natalensis were withdrawn afrer anaesthesia with ether; those from birds, reptiles and frogs after decapitation. The fishes were sacrificed by blows on the head and bleeding: the molluses and crustaceans by dividing central nerve-cords according to Kükenthal, Matthes, and Renner (1967). The dissection of the animals was performed according to Ellenberger and Baum (1912), Kükenthal, and others (1967), and Koch (1970). Only adult animals were used.

All tissues were frozen by $\mathrm{CO}_{2}$ snow immediately after the withdrawal, were stored at $-20^{\circ} \mathrm{C}$. for maximally 4 weeks, and then assaved for their histamine concentration.

* We thank Dr. Rocca and Dr. Martin. from the Stazione Zoologica in Naples, very much for their advice and support in this investigation. 


\section{Reagents and Drugs}

For the fluorimetric determination of histamine the following reagents were used: histamine dihydrochloride purissimum, o-phthaldialdehyde purissimum p.a. (recrystallized from ligroin p.a., b.p. $40-60^{\circ}$ C.) (Fluka, Buchs), methanol, $n$-heptane, inorganic acids and bases as Uvasol (Merck, Darmstadt), n-butanol (chromatography grade Riedel de Haën Hannover), Dowex joW-X8 ( $\mathrm{H}^{+}$, mesh 200-400) (Serva, Heidelberg). If not otherwise stated, only twice-distilled water was used.

For the biological determination of histamine the following drugs were used: glucose, buffers and inorganic salts p.a. (Merck, Darmstadt), atropine (from the university's pharmacy), methysergide, antazoline (Ciba, Basle), mepyramine maleate (Bayer, Leverkusen), pentobarbitone (Nembutal, Abbot. Ingelheim), acerylcholine (Hoffmann-La Roche, Grenzach), serotonin creatinine sulphate (Fluka, Buchs, Switzerland).

Determanation and Identification of Histamine Determination of Histamine

Histamine in the tissues was measured fiuorimetrically according to Shore, Burkhalter, and Cohn (1959) and Lorenz, Benesch and others $(1970)$ and by the bioassay according to Guggenheim and Loffler $(1916)$ in the modification of Barsoum and Gaddum (1935). About 8500 determinations were performed.

For the method of Shore and others (1959) and the bioassay, the tissue pieces were homogenized with 9 parts by volume of $0.4 \mathrm{MHClO}$, and centrifuged at $\mathrm{r} 800 \mathrm{~g}$. Four ml. of the supernatant were extracted with alkaline $n$-butanol, washed with salt-saturated $0.1 M \mathrm{NaOH}$, and again extracted with $0.1 \mathrm{M} \mathrm{HCl}$ according to Shore and others (1959). Histamine in the aqueous phase was then either determined fluorimetrically following the condensation with o-phthaldialdehyde or measured by the bioassay on the isolated atropinized guinea-pig ileum following the neutralization of the $0.1 M \mathrm{HCl}$ solution with $0.1 M \mathrm{NaOH}$.

The most commonly used fuorimetric method was that of Lorenz, Benesch, and others (1970). The tissues were homogenized as described above. Four ml. of the same supernatant, which was used for the bioassay, were adjusted to $p \mathrm{H} 6.5$, chromatographed on Dowex $50 \mathrm{~W}-\mathrm{X8}$, and histamine was determined in the diluted eluate after condensation with o-phthaldialdehyde.

\section{Identification of Histamine}

The identification of histamine in the different tissues was carried out by chemical and biological methods.

According to Carlini and Green (1963) the inhibition of the contraction of the isolated guineapig ileum by small doses of a specific antihistaminic drug can be considered as a reliable method for the identification of histamine. Because of its simplicity we used this procedure to examine the specificity of the assays for all tissues so far investigared in this study. Mepyramine $\left(\mathrm{IO}^{-7} \mathrm{M}\right.$ final concentration) and antazoline $\left[10^{-6} \mathrm{M}\right.$, according to Werle and Lorenz (1970)] were injected into the bath fluid as well as methysergide $\left(10^{-6} \mathrm{M}\right)$ as a specific antagonist to serotonin. Furthermore, the results of the fluorimetric method of Shore and others (1959) were compared with those of the assay of Lorenz, Benesch, and others (1970) in tissues of man, dogs, pigs, and guinea-pigs. The results of the fluorimetric determination after chromatography on Dowex 50 were compared with those of the bio-assay for all tissues so far investizated in this publication. An agreement of the histamine values, obtained by the different determination and isolation methods, was considered as a further argument for the identity of the substance isolated from the tissues with authentic histamine, which was always added to tissue extracts for the determination of the recovery.

Following the purification procedure according to Lorenz and others (197I), the tissue extracts from pig stomach and ileum were compared with authentic histamine using thin-layer chromatography in 8 different solvent systems (ef. Lorenz and others, 1971). Finally, the fiuorescence spectra of authentic histamine were compared with those of tissue extracts from numerous tissues of man, dogs, pigs: sheep, rats, and guinea-pigs after chromatography on Dowex 50, as already reported (Lorenz, Benesch, and others, 1970; Lorenz and others, 1971).

The histamine content of the tissues was expressed in $\mu \mathrm{g}$. histamine dihydrochloride per $\mathrm{g}$. fresh weight. The statistical calculations were carried out with the aid of a desk computer (Programma i02, Olivetti, Italy). The zoological classification of the animals was performed according to Storer and Usinger (1965), Kükenthal and others (1967), and Wurmbach (1971).*

\section{RESULTS}

CoMparison of TWo FlUORIMETRIC METhods FOR THE DETERMINation OF HISTAMINE AND IDENTIFICATION OF Histamine in Various Tissue Extracts

The high degree of correspondence between the values of two different fluorimetric assays for histamine (Table $I$ ) was considered as an argument for the identity of the substance isolated from human and dog tissues with authentic histamine, especially because

* We thank Professor Fr. Seidel, Ph.D., formerly director of the Institute of Zoology, University of Marburg/Lahn, very much for his advice and the support of this investigation. 
the high specificity of the ion-exchange method in tissues had been demonstrated (Lorenz, Barth, and Werle, 1970 ; Lorenz and others, 1971 ). Even if three different purification procedures were used for the fluorimetric which were determined fluorimetrically following Dowex chromatography, were in no case significantly different from those which were measured by bioassay. The contractions of the guinea-pig ileum elicited by the

Table 1.-Comparison of the Results of the Butanol Extraction Method according to Shore AND OTHERs (1959) WTTH ThOSE OF THE DOWEX 50 METHOD ACCORDING to LORENZ AND OTHERs (1970) in Tissues of MAN aNd DOG

Histamine Concentration ( $\mu$ g. per g. fresh weight)

\begin{tabular}{|c|c|c|c|c|c|}
\hline \multicolumn{3}{|c|}{ Man } & \multicolumn{3}{|c|}{ Dog } \\
\hline Tissue & $\begin{array}{l}\text { Butanol } \\
\text { Extraction }\end{array}$ & Dowex 50 & Tissue & $\begin{array}{l}\text { Butanol } \\
\text { Extraction }\end{array}$ & Dowex $5^{\circ}$ \\
\hline $\begin{array}{l}\text { Gastric mucosa, } \\
\quad \text { corpus } \\
\text { antrum } \\
\text { Jejunum } \\
\text { Ileum } \\
\text { Colon (ascending) } \\
\text { Sigma } \\
\text { Rectum } \\
\text { Mesentery } \\
\text { Pancreas } \\
\text { Lungs } \\
\text { Thyroid gland } \\
\text { Muscle } \\
\text { Abdominal rectus } \\
\text { External oblique } \\
\text { Fat, subcutaneous } \\
\\
\text { umbilical } \\
\text { anal } \\
\text { mesenteric }\end{array}$ & $\begin{array}{l}19.0 \pm 6.8 \\
14.2 \pm 5.1 \\
14.3 \pm 1 \cdot 1 \\
15.9 \pm 5 \cdot 1 \\
9 \cdot 0 \pm 3 \cdot 1 \\
8.4 \\
5.9 \pm 2.4 \\
1.4 \\
4 \cdot 1 \pm 1.8 \\
12.3 \pm 3.8 \\
0.4 \pm 0.1 \\
2.7 \pm 1 \cdot 1 \\
0.5 \pm 0.3\end{array}$ & $\begin{array}{r}20.2 \pm 8.8 \\
14.6 \pm 4.5 \\
12.3 \pm 2.2 \\
14.8 \pm 6.4 \\
8.1 \pm 1.4 \\
7.8 \\
5.8=1.9 \\
1.7 \\
3.5=1.6 \\
14.4 \pm 4.3 \\
0.4=0.1 \\
2.8 \pm 0.8 \\
0.6 \pm 0.4\end{array}$ & $\begin{array}{l}\text { Kidney } \\
\text { Ureter } \\
\text { Urinary bladder } \\
\text { Muscles } \\
\text { Masseter } \\
\text { Laryngeal } \\
\text { Sternomastoid } \\
\text { Triceps brachii } \\
\text { Extensors digitorum } \\
\text { Deltoid } \\
\text { Intercostal } \\
\text { Rectus } \\
\text { External oblique } \\
\text { Psoas } \\
\text { Autochthonous back } \\
\text { muscles } \\
\text { Gluteus maximus } \\
\text { Biceps femoris } \\
\text { Semitendinosus } \\
\text { Gastrocnemius } \\
\text { Diaphragm }\end{array}$ & $\begin{array}{r}2 \cdot 3 \\
30 \cdot 8 \\
7 \cdot 1 \\
1 \cdot 3 \\
2 \cdot 1 \\
1 \cdot 7 \\
2 \cdot 1 \\
1 \cdot 4 \\
1 \cdot 8 \\
3 \cdot 0 \\
1 \cdot 9 \\
3 \cdot 4 \\
1 \cdot 7 \\
1 \cdot 7 \\
2 \cdot 4 \\
2 \cdot 8 \\
1 \cdot 9 \\
3 \cdot 3 \\
7 \cdot 0\end{array}$ & $\begin{array}{r}2 \cdot 4 \\
32 \cdot 5 \\
6 \cdot 2 \\
1 \cdot 1 \\
2 \cdot 0 \\
1 \cdot 7 \\
1 \cdot 7 \\
1 \cdot 3 \\
1 \cdot 6 \\
2 \cdot 7 \\
1 \cdot 5 \\
3 \cdot 0 \\
1 \cdot 7 \\
2 \cdot 3\end{array}$ \\
\hline
\end{tabular}

$\bar{x} \pm$ S.D. In the case of human tissues, only $1-8$ organs were obtained from the same individual; in dogs each tissue of one series from the same animal. In $\operatorname{man} n=2-4$, in $\operatorname{dogs} n=2$. For further conditions see Methods.

determination of histamine in organs of pigs and guinea-pigs (butanol extraction, ionexchange chromatography, and a combination of both methods), no significant differences between the histamine concentrations of these tissues could be observed (Lorenz and others, 1971).

The fluorescence spectra of the substances isolated from tissues of man, dogs, pigs, sheep, rats, and guinea-pigs, all corresponded to those of authentic histamine. In all tissues investigated the histamine concentrations, tissue extracts and by authentic histamine were completely abolished by mepyramine and antazoline, but not by methysergide and atropine, which totally blocked the equivalent contractions of the gut induced by serotonin and acetylcholine. Thus, the substances isolated from the tissues seemed to be sufficiently identified as histamine.

Only in the extracts of pig stomach and ileum was histamine identified by thin-layer chromatography, as already reported (Lorenz and others, 1971). 
Histamine Concentrations in Mammatian Tissurs

\section{Histamine Concentrations in Human Tissues}

(Table II)

Histamine was detected in all 34 human tissues investigated. The highest concentrations were found in lungs, stomach, and intestinum, the lowest in kidney, subcutaneous connective tissue, and muscles. In several tissues, which showed pathological alterations (Meckel's diverticulum, adenocarcinoma of the rectum, and adenoma of the

Table II.-Histamine Concentrations of Human Tissues

\begin{tabular}{|c|c|c|c|}
\hline \multirow{2}{*}{ T ISSUE } & \multirow{2}{*}{$n$} & \multicolumn{2}{|c|}{ Histamine CONCENTRATION ( $\mu$ g. pet g.) } \\
\hline & & $\bar{x} \pm S . D$ & Extreme Values \\
\hline $\begin{array}{l}\text { Gastro-intestinal Tract } \\
\text { Gastric mucosa } \\
\text { Fundus } \\
\text { Corpus } \\
\text { Antrum } \\
\text { Duodenum } \\
\text { Jejunum } \\
\text { Ileum } \\
\text { Appendix } \\
\text { Meckel's diverticulum } \\
\text { Colon (ascending) } \\
\text { Sigma } \\
\text { Rectum } \\
\text { Adenocarcinoma } \\
\text { Ampulla } \\
\text { Liver } \\
\text { Gall-bladder } \\
\text { Pancreas } \\
\text { Head } \\
\text { Tail } \\
\text { Mesentery }\end{array}$ & $\begin{array}{r}4 \\
19 \\
15 \\
3 \\
6 \\
8 \\
2 \\
1 \\
5 \\
13 \\
11 \\
1 \\
2 \\
33 \\
2\end{array}$ & 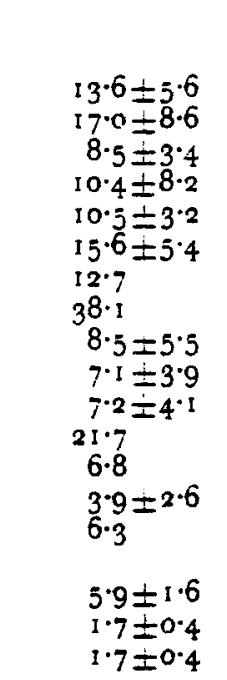 & $\begin{array}{l}6 \cdot 1-18 \cdot 9 \\
5 \cdot 0-39 \cdot 0 \\
3 \cdot 5-13 \cdot 0 \\
5 \cdot 0-16 \cdot 2 \\
6 \cdot 0-14 \cdot 3 \\
8 \cdot 3-25 \cdot 0 \\
- \\
- \\
3 \cdot 3-18 \cdot 4 \\
2 \cdot 3-13 \cdot 2 \\
1 \cdot 2-12 \cdot 8 \\
- \\
- \\
1 \cdot 6-16 \cdot 6 \\
- \\
4 \cdot 2-8 \cdot 1 \\
1 \cdot 2-2 \cdot 2 \\
-\end{array}$ \\
\hline $\begin{array}{l}\text { Remaining Tissues } \\
\text { Lungs } \\
\text { Kidney } \\
\text { Parenchyma } \\
\text { Capsula } \\
\text { Pelvis } \\
\text { Ureter } \\
\text { Prostate (adenoma) } \\
\text { Spleen } \\
\text { Thyroid gland } \\
\text { Skin } \\
\text { Abdominal } \\
\text { Anal } \\
\text { Subcutaneous fat } \\
\text { Abdomen } \\
\text { Anal } \\
\text { Arm } \\
\text { Mesenteric fat } \\
\text { Mammary gland } \\
\text { Muscle (rectus) }\end{array}$ & $\begin{array}{l}2 \\
2 \\
2 \\
2 \\
3 \\
3 \\
3\end{array}$ & $\begin{array}{l}24 \cdot 1=17.6 \\
1.2 \\
1 \cdot 9 \\
2.5 \\
6 \cdot 4 \\
7 \cdot 6 \pm 2.7 \\
2 \cdot 8 \pm 1.8 \\
0.4 \pm 0.1 \\
4 \cdot 8 \pm 3.4 \\
8 \cdot 1 \pm 3.7 \\
0.8 \pm 0.5 \\
0.9 \\
2 \cdot 0 \pm 0.4 \\
1 \cdot 2 \pm 0.9 \\
7.2 \\
1.8 \pm 0.8\end{array}$ & $\begin{array}{c}12 \cdot 6-66 \cdot 0 \\
= \\
\bar{Z} \\
5.5-10.7 \\
1.4-4.5 \\
0.2-0.5 \\
1.7-7.9 \\
4 \cdot 1-11.5 \\
0.2-2.0 \\
1.5-2.3 \\
0.3-2.6 \\
0.8-3.1\end{array}$ \\
\hline
\end{tabular}

Mean values of tissues which were obtained in a total number of $1-8$ from the same individual. From intestinal tissues, the whole wall was investigated. For further conditions see Methods. 


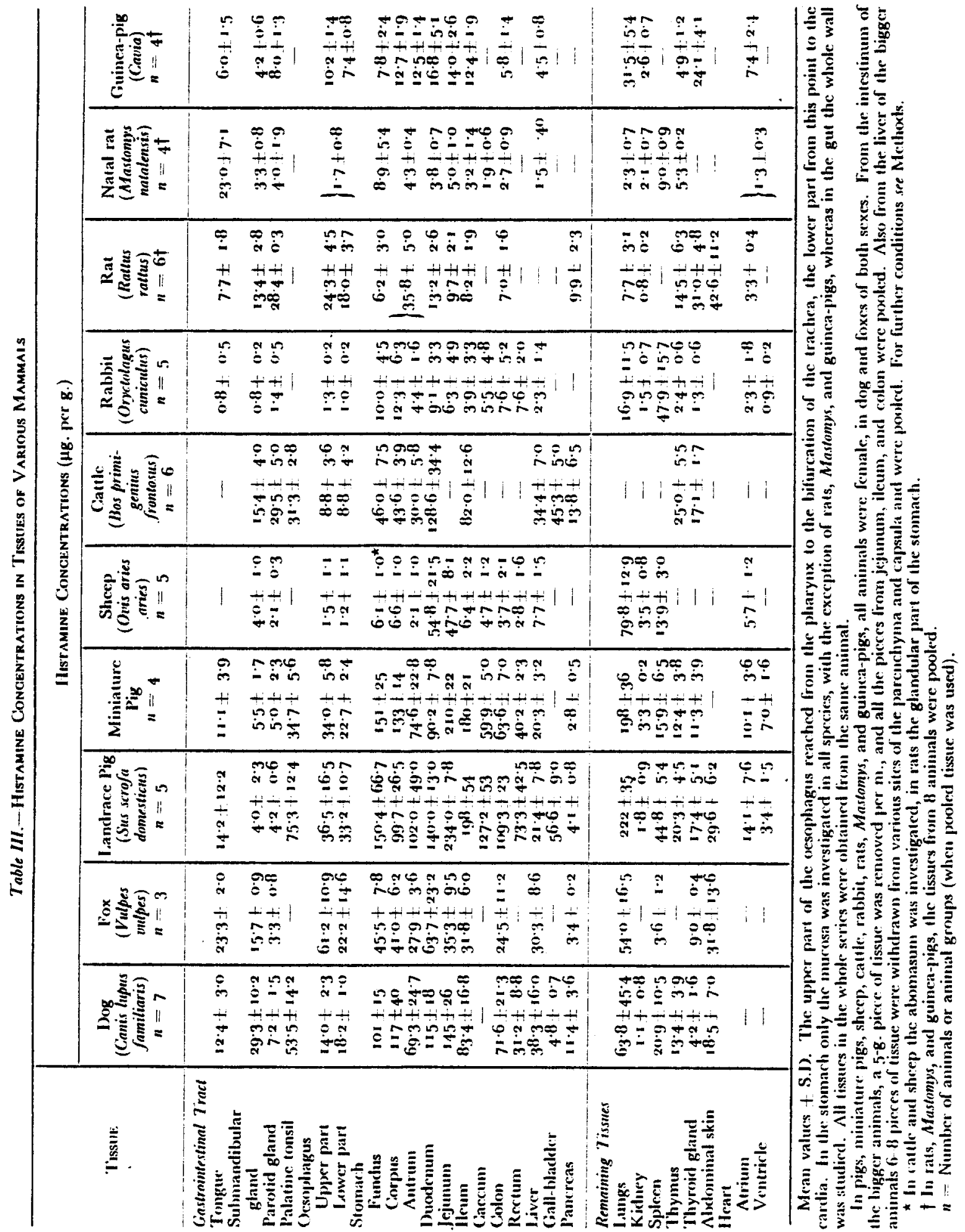


prostate), relatively high histamine contents were measured. In the gastro-intestinal tract the histamine concentration decreased from oral to aboral. The scattering of the histamine values from individual to individual was especially large in this organ sustem as compared with other tissues.
Histamine Concentrations in Tissues of Various Other Mammals (Table III)

Histamine could be found in all mammaiian tissues, but considerable differences occurred from tissue to tissue. Histamine concentrations below I $\mu \mathrm{g}$. per $\mathrm{g}$. were measured in only a few organs, such as the

Table IV.-Histamine Concentrations of Single Tissues of Special Interest in Various Spectes

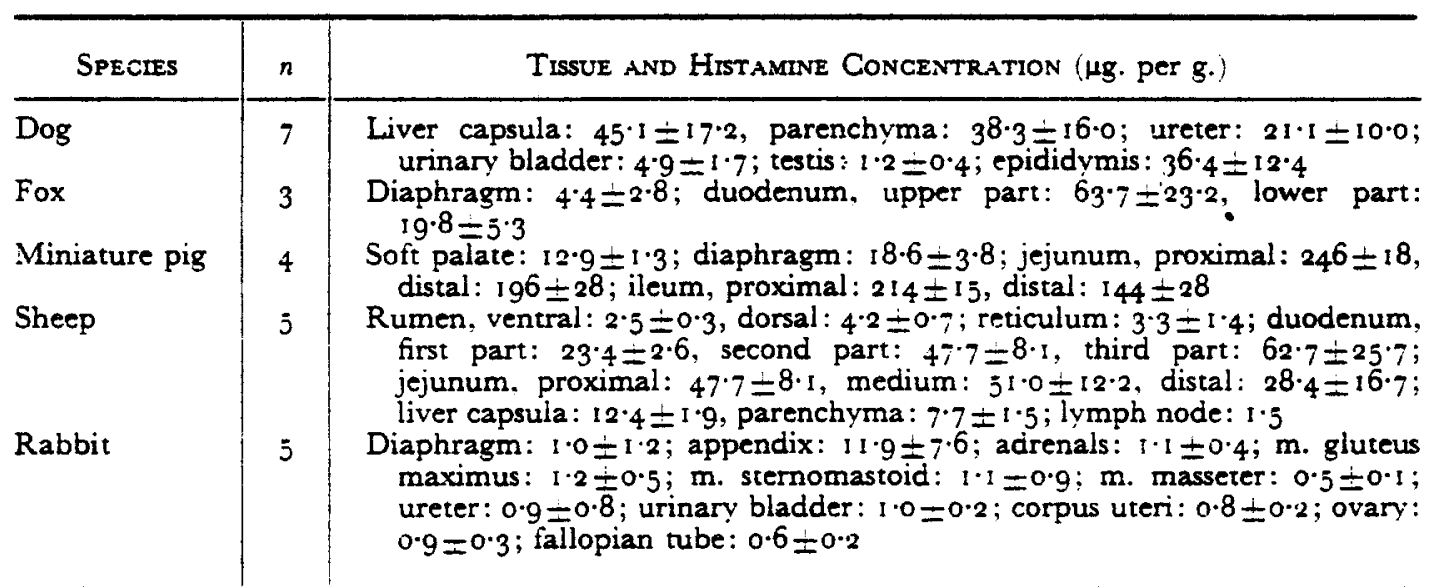

Mean values $=$ S.D. All tissues in the whole series were obtained from the same animal. The proximal part of the intestinum means the first $\mathrm{m}$., the distal one the last $\mathrm{m}$. For further conditions see Table III and Methods.

Table V.-Histamine Concentrations in Various Muscles of the Dog

\begin{tabular}{|c|c|c|}
\hline \multirow{2}{*}{ TISSUE } & \multicolumn{2}{|c|}{ Histamme Concentration ( $\mu$ g. per g.) } \\
\hline & $\bar{x} \div$ S.D. & Extreme Values \\
\hline $\begin{array}{l}\text { Masseter } \\
\text { Laryngeal muscles } \\
\text { Sternomastoid } \\
\text { Deltoid } \\
\text { Intercostal muscles } \\
\text { Abdominal recrus } \\
\text { External oblique } \\
\text { Psoas } \\
\text { Autochthonous back } \\
\text { muscles } \\
\text { Extensors digitorum } \\
\text { Triceps brachii } \\
\text { Biceps femoris } \\
\text { Gluteus maximus } \\
\text { Semitendinosus } \\
\text { Gastrocnemius } \\
\text { Diaphragm }\end{array}$ & $\begin{array}{r}1 \cdot 9 \pm 1 \cdot 2 \\
2 \cdot 7 \pm 2 \cdot 2 \\
2 \cdot 2 \pm 0 \cdot 8 \\
2 \cdot 0 \pm 1 \cdot 3 \\
2 \cdot 5 \pm 1 \cdot 9 \\
1 \cdot 9 \pm 0 \cdot 8 \\
3 \cdot 2 \pm 2 \cdot 2 \\
2 \cdot 5 \pm 1 \cdot 7 \\
2 \cdot 7 \pm 2 \cdot 2 \\
2 \cdot 1 \pm 1 \cdot 5 \\
2 \cdot 1 \pm 1 \cdot 2 \\
2 \cdot 7 \pm 1 \cdot 3 \\
2 \cdot 3 \pm 1 \cdot 1 \\
2 \cdot 3 \pm 1 \cdot 2 \\
2 \cdot 8 \pm 1 \cdot 4 \\
12 \cdot 1 \pm 4.7\end{array}$ & $\begin{array}{l}0.8-4.2 \\
1 \cdot 0-7.3 \\
1 \cdot 0-3.6 \\
0.7-3.8 \\
0.7-6.3 \\
0.9-2 \cdot 9 \\
0.8-7 \cdot 7 \\
0.8-5 \cdot 0 \\
1 \cdot 0-7 \cdot 3 \\
1 \cdot 1-5.2 \\
0.9-4.6 \\
1 \cdot 0-5 \cdot 1 \\
0.9-3.8 \\
0.3-4.1 \\
0.3-5.0 \\
5.8-17.4\end{array}$ \\
\hline
\end{tabular}

Mean vaiues from 7 animals of both sexes. For further conditions ses Table III and Methods. 
tongue, submandibular gland, and heart of the rabbit and in rat kidney. Histamine concentrations higher than $100 \mu \mathrm{g}$. per $\mathrm{g}$. were than $20 \mu \mathrm{g}$. per $\mathrm{g}$. On the other hand, there are animais with high histamine contents in numerous tissues, such as dogs, foxes, and

Table VI.-Histamene Concentrattons in Tissues of Birds

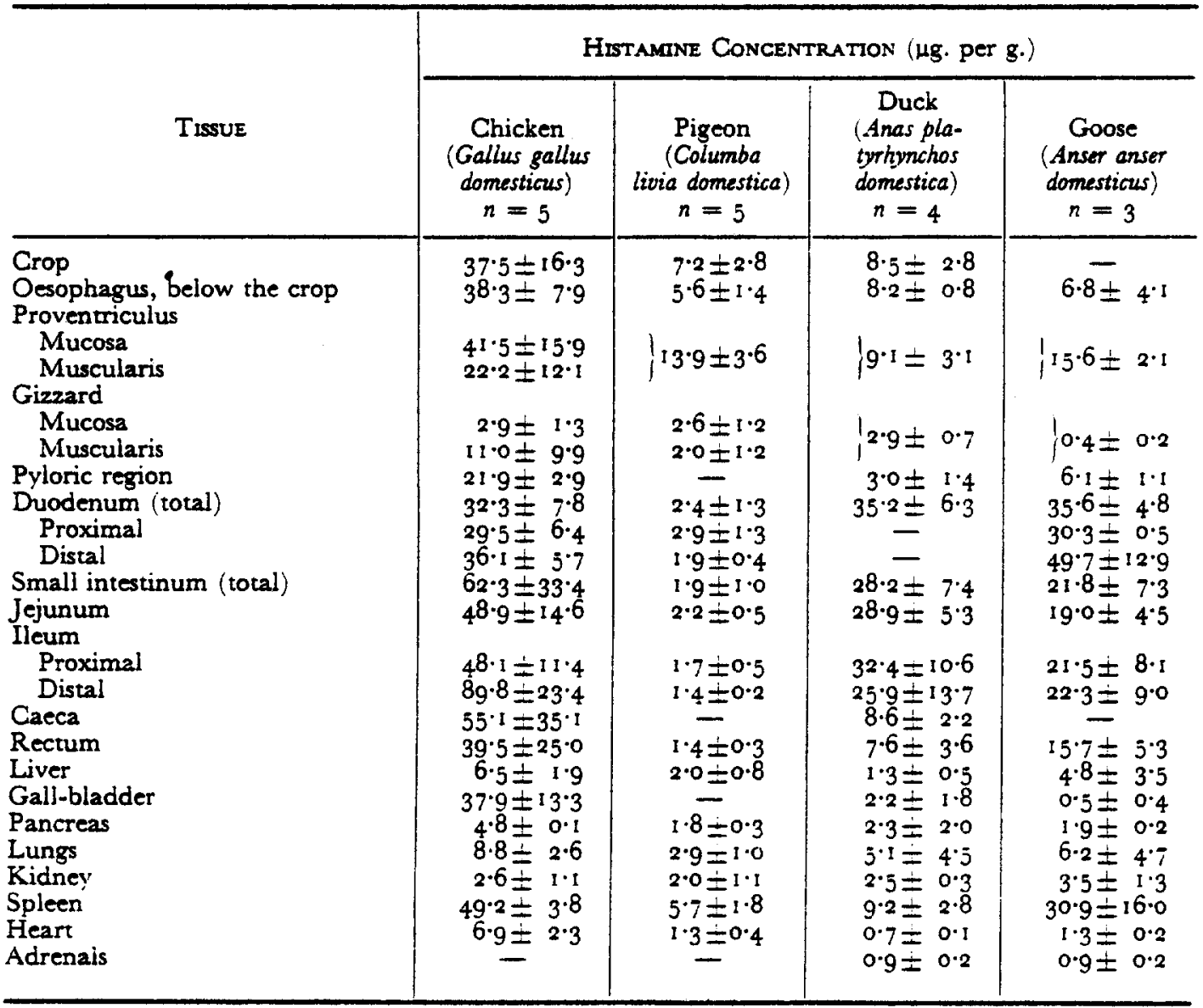

Mean values \pm S.D. All tissues in the whole series were obtained from the same animal, which is true for all following tables. All individuals were female. Proximal means the proximal half, distal the distal one. For further conditions see Methods.

detected only in the gastro-intestinal tract and partly in the lungs of dogs, pigs, and cattle. Thus, about go per cent of all histamine concentrations in the tissues are situated within the range of $\mathrm{I}-100 \mu \mathrm{g}$. per $\mathrm{g}$.

The values shown in Tables $I I, I I I$ demonstrate that there is no mammalian species which is really poor in histamine, since in one or several tissues of every species histamine concentrations can be found which are more pigs, whereas in rabbits and Mastomys natalensis many organs are relatively poor in histamine.

There was no tissue found in mammals which showed in all species investigated a relatively high histamine concentration. Always one or two exceptions could be detected, such as the gastric mucosa of sheep or Masto$m \nu s$, the intestinum of rabbits, rats, or Mastomys, and the lungs of rats, which had 
only a medium histamine content. Tissues with relatively low histamine concentrations in all species were kidney and heart ventricle. Organs with a histamine content, which e.g., by d-tubocurarine (Macintosh and Paton, 1949), can cause pathophysiological reactions in an animal of a very different degree.

Table VII.-Histamne Concentrations in Tissues of Reptiles

\begin{tabular}{|c|c|c|c|}
\hline \multirow[b]{2}{*}{ Tissue } & \multicolumn{3}{|c|}{ Histamini: Concentration ( $\mu$ g. per g.) } \\
\hline & $\begin{array}{l}\text { European Pond Turtle } \\
\text { (Emys orbicularis) }\end{array}$ & $\begin{array}{l}\text { Caspian Pond Turtle } \\
\text { (Clemmys caspica) }\end{array}$ & $\begin{array}{c}\text { Gecko } \\
\text { (Tarentola } \\
\text { mauritanica) }\end{array}$ \\
\hline $\begin{array}{l}\text { Oesophagus } \\
\text { Stomach } \\
\text { Fundus } \\
\text { Corpus } \\
\text { Antrum } \\
\text { Duodenum } \\
\text { Jejunum } \\
\text { Ileum } \\
\text { Colon } \\
\text { Liver } \\
\text { Pancreas } \\
\text { Trachea } \\
\text { Lungs } \\
\text { Spleen } \\
\text { Kidney } \\
\text { Heart } \\
\text { Abdominal muscles } \\
\text { Abdominal skin }\end{array}$ & $\begin{array}{r}4 \cdot 7 \\
9 \cdot 1 \\
10 \cdot 1 \\
4 \cdot 5 \\
0 \cdot 7 \\
0.5 \\
0.4 \\
0.9 \\
1 \cdot 3 \\
3 \cdot 1 \\
2 \cdot 2 \\
2 \cdot 3 \\
18 \cdot 7 \\
4 \cdot 7 \\
4 \cdot 9 \\
0.9 \\
-\end{array}$ & $\begin{array}{r}16 \cdot 3 \\
12 \cdot 1 \\
11 \cdot 2 \\
3 \cdot 3 \\
4 \cdot 4 \\
4 \cdot 2 \\
4 \cdot 2 \\
5 \cdot 6 \\
18 \cdot 8 \\
15 \cdot 9 \\
10 \cdot 7 \\
13 \cdot 4 \\
352 \cdot 0 \\
12 \cdot 6 \\
17 \cdot 7 \\
3.6 \\
\end{array}$ & $\begin{array}{r}17 \cdot 6 \\
18 \cdot 3 \\
15 \cdot 6 \\
15 \cdot 6 \\
6 \cdot 8 \\
2 \cdot 1 \\
6 \cdot 5 \\
15 \cdot 6 \\
10 \cdot 4 \\
\overline{8 \cdot 0} \\
12 \cdot 4 \\
62 \cdot 4 \\
14 \cdot 3 \\
21 \cdot 7 \\
= \\
-\end{array}$ \\
\hline
\end{tabular}

Mean values from two female animals. $-=$ means ' not investigated '. For further conditions see Methods.

showed great species differences, were the submandibuiar gland, liver, spleen, and thyroid gland. Generally there was a considerable species variability of the histamine concentration in tissues.

In the gastro-intestinal tract of all species the histamine content decreased from oral to aboral.

In several mammals, in addition to those described in Table III, the histamine concentrations of those tissues were particularly measured (Tables $I V, V$ ) in which a physiological or pathophysiological role of histamine had been considered by various investigators (for a survey see Lorenz and Werle, 1974). The histamine content of striated muscles in the dog showed only small variations within the same individual, but considerable differences within the same species (Table $V$ ). Thus, histamine release from these muscles,
Histamine Concentrations in Tissues of Birds (Table VI)

In all tissues of the birds investigated, which belong to three different orders, histamine couid be detected, but its distribution varied considerably from organ to organ. The highest histamine contents were measured in the mucosa of the glandular part of the stomach (proventriculus). In three species high levels were also found in the small intestinum and spleen. Relatively low histamine concentrations were regularly found in the pancreas, the kidney, and in three species also in the heart. As in mammals the histamine content of the gut decreased from oral to aboral.

In some organs of the pheasants (Phasionus colchicus colchicus) the following histamine contents were determined ( $\bar{x}, n=2, \mu \mathrm{g}$. per g.): crop I.9, oesophagus below the crop $2 \cdot 4$, fundic region of the proventriculus 13.6 , gizzard 
$2 \cdot 2$, pyloric region of the proventriculus 0.4 , liver $2 \cdot 6$.

Although in no tissue of the birds studied could as high histamine concentrations be measured as in some mammalian organs (which may be a casual event, owing to the election of the species), on the average the histamine values of the avian tissues were in the same range of concentrations as those of mammalian tissues.

\section{Histamine Concentrations in Tissues of Reptiles} (Table VII)

In the three reptilian species histamine was found in all tissues investigated, but its distribution varied from organ to organ. The histamine in the organs showed only small variations, with the exception of the upper part of the gastro-intestinal tract, which was relatively rich in histamine. Generally, the histamine content of the frog tissues was low as compared with that of the other species investigated. These findings may not be representative for all amphibians, but have to be considered clearly as an exception among the other vertebrates studied until now.

Histamine Concentrations in Tissues of the Bony Fishes (Table IX)

For the first time no histamine could be detected in a tissue of an animal. Despite the high sensitivity of the fluorimetric method,

Table VIII.-Histamine Concentrations in Tissues of the Frog (Rana pipiens)

\begin{tabular}{|c|c|c|c|}
\hline Tissue & 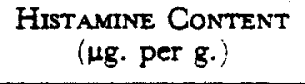 & Tissue & 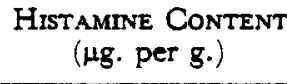 \\
\hline $\begin{array}{l}\text { Roof of the } \\
\text { pharynx } \\
\text { Oesophagus } \\
\text { Stomach } \\
\text { Jejunum } \\
\text { Ileum } \\
\text { Colon } \\
\text { Liver }\end{array}$ & $\begin{array}{l}3 \cdot 6 \pm 1 \cdot 2 \\
2 \cdot 7 \pm 0.9 \\
2 \cdot 6 \pm 0.8 \\
1 \cdot 2 \pm 0.2 \\
1 \cdot 0 \pm 0.2 \\
0.6 \pm 0.3 \\
0.6 \pm 0.3\end{array}$ & $\begin{array}{l}\text { Lungs } \\
\text { Heart } \\
\text { Kidney } \\
\text { Testis } \\
\text { Epididymis } \\
\text { M. quadratus femoris } \\
\text { M. gastrocnemius }\end{array}$ & $\begin{array}{l}0.8 \pm 0.3 \\
0.7=0.2 \\
1.1=0.1 \\
0.4=0.1 \\
0.6=0.2 \\
0.4=0.1 \\
0.3=0.1\end{array}$ \\
\hline
\end{tabular}

Mean values $=$ S.D. from 3 experiments, in each case the tissues from 5 male animals were pooled. For further conditions see Methods.

highest histamine concentrations were found in the spleen and in the corpus region of the stomach, but only low histamine contents were determined in the intestinum. Since a high histamine concentration of the spleen was measured both in reptiles and in birds, this finding could be a further argument for a close affinity of these two classes in the phylum chordata (Sauropsides). On the average, the histamine concentrations of reptilian tissues are in the same order of magnitude as in mammals and birds.

Histamine Concentrations in Tissues of the Frog (Rane pipiens) (Table VIII)

As in mammals, birds, and reptiles, histamine was detected in all tissues which were studied in the frog. The distribution of which was used as combined method under conditions as for the determination of plasma histamine (Lorenz, Reimann, Barth, Kusche, Meyer, Doenicke, and Hutzel, 1972a) and was capable of measuring a $0.5 \mathrm{ng}$. histamine per $g$. tissue, no histamine could be measured in the tissue extracts of the carp ovary. Furthermore, authentic histamine added to the ovary extracts showed the same recovery as that which was combined with other tissue homogenates. Thus, the presence of substances interfering with both the fluorimetric and the biological assay of histamine could be excluded.

Generally the organs of bony fishes, which belonged to three different orders of the class Osteichtyes, were relatively poor in histamine, with the exception of the gastric mucosa of 
most species and the kidney of the pike. Only the carp showed low histamine concentrations along the whole gastro-intestinal tract, whereas the histamine contents of the other tissues were mostly relatively low. On the average the histamine concentrations in the

Table IX.-Histamine Concentrations in Tissues of Bony Fishes

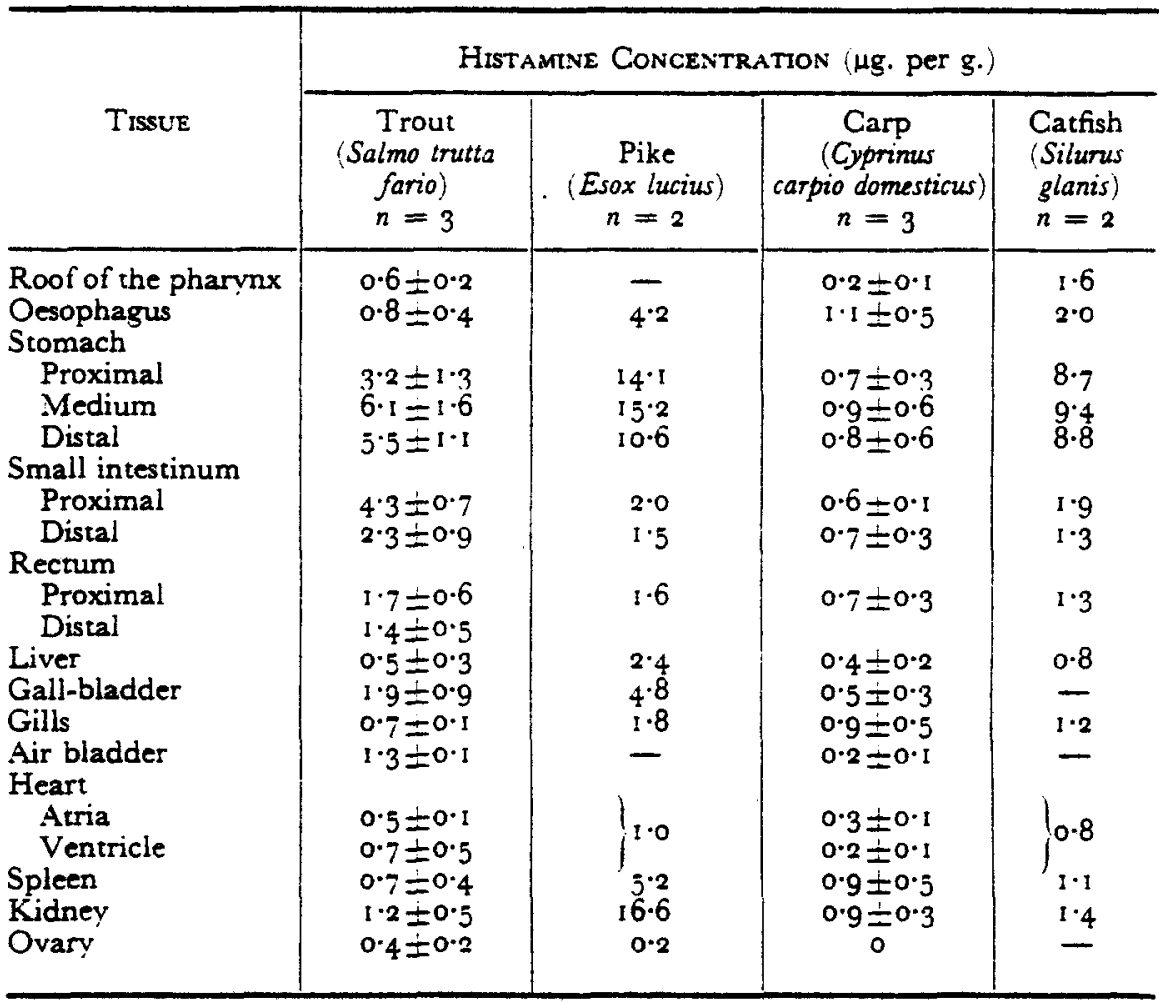

Mean values $=$ S.D., only female animals were tested. 'Stomach ' in carps means the widening of the gut following the oesophagus, which immediately follows the gills. For further conditions see Methods.

but it is known as a 'stomachless' fish (see Wurmbach, 1971). Among all species which were studied for their histamine content (Lorenz and Werie, I974), the carp was found to be the animal poorest in histamine. The distribution of histamine in the bony fishes was fairly uniform.

Histamine Concentrations in Tissues of Cartilaginous Fishes (Table $X$ )

No histamine could be measured in pancreas, rectal gland, ovary, and brain of cartilaginous fishes. The other tissues investigated contained histamine in varying concentrations. The highest values were observed again in the gastro-intestinal tract, tissues of cartilaginous fishes are in the same order of magnitude as those of mammals, birds, and reptiles.

\section{Histamine Concentrations in $T$ issues of Tunicates and Lanselets}

Tunicates and lancelets are the two primitive subphyla of the phylum chordates. Thus, we investigated the distribution of histamine in Branchiostoma lanceolatum. The intestinum contained histamine in a concentration of $2 \mu \mathrm{g}$. per $\mathrm{g}$. (tissues pooled from 20 animais), whereas the pharynx and the rest of the body were found to be free from histamine. Also in two species of the tunicates, histamine could be found only in the stomach and intestinum 


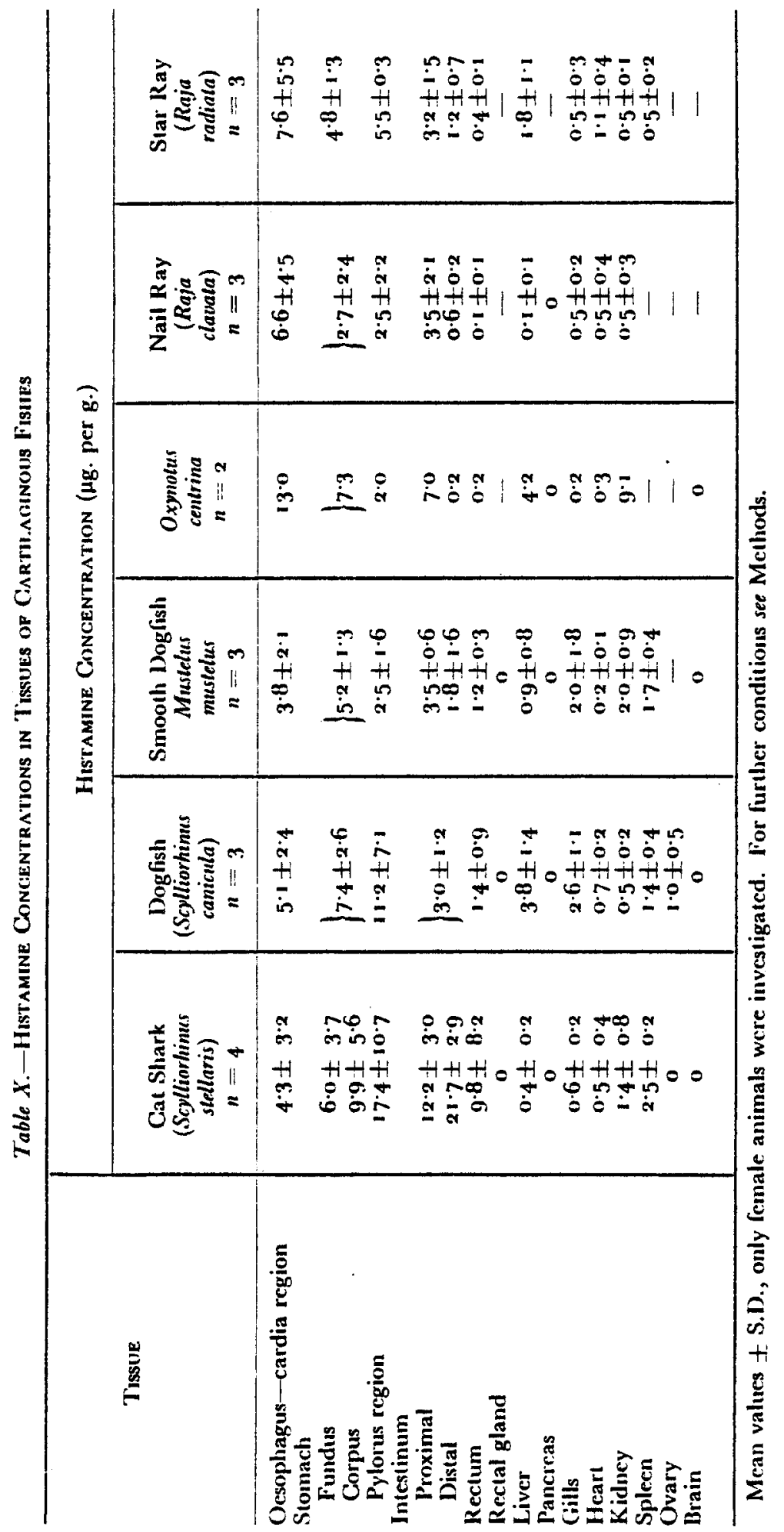


(Table $X I$ ), in which relatively low histamine concentrations were measured.

Histamine Concentrations in Tissues of Molluscs and Echinoderms

From the phylum Mollusca, two highly developed species, sepia and octopus, were investigated for their histamine content in various tissues (Table XII). No histamine couid be found in the posterior salivary glands, in many parts of the intestinum, in the gills, or the ovary. The other tissues contained variable concentrations of histamine. In octopus the highest values were found in the nerve ganglia around the pharynx, which may be considered as a primitive brain, whereas in sepia the liver showed the highest histamine concentration.

Table XI.-Histamine Concentrations in Tissues of Tunicates

\begin{tabular}{|c|c|c|}
\hline \multirow{2}{*}{ Tissues } & \multicolumn{2}{|c|}{ Hustamine Content ( $\mu \mathrm{g}$. per g.) } \\
\hline & Ciona intestinalis & $\begin{array}{c}\text { Haiocynthia } \\
\text { papillosa }\end{array}$ \\
\hline $\begin{array}{l}\text { Branchial sac } \\
\text { Stomach } \\
\text { Heart } \\
\text { Intestinum } \\
\text { Gonad }\end{array}$ & $\begin{array}{l}0 \\
1 \cdot 8 \\
0 \\
0 \cdot 1 \\
0\end{array}$ & $\begin{array}{l}0 \\
1 \cdot 2 \\
0 \\
0 \cdot 4 \\
0\end{array}$ \\
\hline
\end{tabular}

Mean values from 2 experiments. For each determination the tissues of $10-15$ animals were pooled. For further conditions see Methods.

Toble XII.-Histamine Concentrations in Tissues of Cephalopoda

\begin{tabular}{|c|c|c|}
\hline \multirow[b]{2}{*}{ Tissue } & \multicolumn{2}{|c|}{ Histamine Concentration (ug. per g.) } \\
\hline & $\begin{array}{c}\text { Cuttlefish } \\
\text { (Sepria officinalis) } \\
n=2-3\end{array}$ & $\begin{array}{c}\text { Octopus } \\
\text { (Octopus vulgaris) } \\
n=2-3\end{array}$ \\
\hline $\begin{array}{l}\text { Posterior salivary glands } \\
\text { Oesophagus } \\
\text { Stomach } \\
\text { Caecum } \\
\text { Liver } \\
\text { Intestinum } \\
\text { Rectum } \\
\text { Gills } \\
\text { Heart } \\
\text { Branchial heart } \\
\text { Kidney } \\
\text { Nidamental gland (NG) } \\
\text { Accessory NG } \\
\text { Ovary } \\
\text { Ink sac } \\
\text { - Brain, } \\
\text { Optical lobe } \\
\text { Supraoesophageal lobe } \\
\text { Suboesophageal lobe }\end{array}$ & $\begin{array}{l}0 \\
1 \cdot 4 \\
5 \cdot 5 \pm 2 \cdot 5 \\
7 \cdot 4 \pm 3 \cdot 8 \\
13 \cdot 1 \pm 6 \cdot 2 \\
- \\
4 \cdot 3 \pm 3 \cdot 0 \\
1 \cdot 1 \\
4 \cdot 7 \pm 2 \cdot 0 \\
4 \cdot 0 \pm 2 \cdot 6 \\
2 \cdot 2 \pm 1 \cdot 0 \\
0.8 \\
4 \cdot 0 \\
1 \cdot 5 \\
0.8 \\
- \\
=\end{array}$ & $\begin{array}{c}0 \\
0.3 \pm 0.1 \\
0 \\
0.3 \pm 0.2 \\
0.5 \pm 0.1 \\
0 \\
0 \\
2.9 \pm 2.3 \\
3.6 \pm 2.4 \\
0.7 \pm 0.2 \\
= \\
0 \\
\\
5.7 \pm 1.8 \\
2.2=0.9 \\
1.6 \pm 0.5\end{array}$ \\
\hline
\end{tabular}

Mean values $=$ S.D. from $2-3$ experiments. The tissues of 10 female animals were pooled. For further conditions see Methods. 
In three species of the echinoderms only a few tissues were studied for their histamine concentration. In the sea-urchin (Paracentrotus lividus) the gut contained $2 \cdot 2 \mu \mathrm{g}$. per $\mathrm{g}$. ( $n$ $=2$, organs pooled from Io animals). In the brittle star (Ophiura exturata) the central gastro-intestinal tract showed $25 \mu \mathrm{g}$. per $\mathrm{g}$., the hepatic caeca in the arms $7.4 \mu \mathrm{g}$. per $\mathrm{g}$.

\section{DISCUSSION}

The reasons for such an extensive study on the occurrence and distribution of histamine in the animal kingdom, which wer: named in the introduction, have now to be discussed in more detail.

1. It seemed necessary to reinvestigate the histamine content of numerous organs and

Table Xill.-Histamine Concentrations in Tissues of Crustaceans

\begin{tabular}{|c|c|c|}
\hline \multirow[b]{2}{*}{ Tissue } & \multicolumn{2}{|c|}{ Histamane Concentration ( $\mu \mathrm{g} \cdot$ per g.) } \\
\hline & $\begin{array}{c}\text { Lobster } \\
\text { (Pelinurus vulgaris) } \\
n=3\end{array}$ & $\begin{array}{c}\text { Crab } \\
\text { (Carcinus maenas) } \\
n=2\end{array}$ \\
\hline $\begin{array}{l}\text { Cardia } \\
\text { Stomach } \\
\text { Liver } \\
\text { Intestinum } \\
\text { Gills } \\
\text { Heart } \\
\text { Antenna } \\
\text { Eyestalk } \\
\text { Mandibular muscles } \\
\text { Seminal vesicle }\end{array}$ & $\begin{array}{c}0.4 \pm 0.3 \\
0.6 \pm 0.3 \\
4 \cdot 8 \pm 3 \cdot 6 \\
0.4 \pm 0.2 \\
5 \cdot 6 \pm 2 \cdot 1 \\
0.3=0 \cdot 2 \\
0 \\
7 \cdot 8 \pm 3 \cdot 1 \\
0 \\
-\end{array}$ & $\begin{array}{c}20.4 \\
20 \cdot 4 \\
180 \\
70 \\
5 \cdot 3 \\
150 \\
400 \\
130\end{array}$ \\
\hline
\end{tabular}

Mean values \pm S.D. from 2-3 experiments. Tissues of the crab were pooled from 20 male animals, only female lobsters were used. For further conditions see Methods.

( $n=2$, organs pooled from 10 animais), whereas in the sea cucumber (Holothuria tubulosa) the intestinum contained $1.4 \mu \mathrm{g}$. histamine per $g$. tissue ( $n=2$, organs pooled from 5 animals).

Histamine Concentrations in Tissues of Crustaceans (Table XIII)

No histamine could be found in the antennae and in the muscles of the lobster (Palinurus vulgaris), whereas in the crab (Carcinus maenas) all tissues investigated contained histamine. The highest concentrations were measured in the eyestalk, where the x-organ, a neurosecretory organ, is localized. For this reason, we investigated also the evestalk of the crayfish (Astacus fuviatilis) and found there the high histamine content of $160 \mu \mathrm{g}$. per $\mathrm{g}$. $(n=$ 2 , tissues pooled from 20 animals;. Thus, the histamine concentrations in the crustacean tissues can be considered as relatively high as compared with those of most chordates. tissues with the aid of methods the specificity of which had been demonstrated by several chemical and biological procedures (Lorenz, Barth, and Werle, 1970; Lorenz, Benesch, and others, 1970; Lorenz and others, 1971). General doubts of the correctness of the commonly used histamine assays, i.e., the fluorimetric method of Shore and others (1959) and the biological determination on the isolated guinea-pig ileum according to Barsoum and Gaddum (1935), have recently arisen (Michaelson and Coffman, 1967; Aures, Davidson, and Hákanson, 1969; Waton, 1971). The direct comparison of the histamine values which were obtained by the bio-assay, the butanol extraction method, the Dowex method, and the combined method (Lorenz, Benesch and others, 1970; Lorenz and others, 1971 ; this publication), by no means justified such an assumption, however. Furthermore, the indirect comparison of the histamine values, which were presented by 
this paper and by many other investigators (for a survey see Lorenz and Werle, 1974), showed such a good correspondence in so many cases that general doubts of the accuracy of the bio-assay and the fiuorimetric methods for determination of histamine cannot exist any longer. Only in the case of tissues with extremely low histamine concentrations, such as certain nervous tissues (Carlini and Green, I963; Kremzner and Pfeiffer, I g66) and of body fluids, on principle one should be cautious with histamine assays; the best isolation procedure giving maximum specificity has to be examined for each single case (Lorenz, Benesch and others, 1970; Lorenz and others, 1971; Lorenz, Huhnd, Kusche, Barth, Haubensak, Hutzel, Schmal, Gerant, Wächter, Matejka, Hahn, and Werle, I 973; Lorenz, Reimann, and others, 1972; Lorenz, Schmal, Reimann, Tauber, Uhlig, Mann, Barth, Kusche, Seidal, Doenicke, Hamelmann, and Werle, 1972).

2. For some of the tissues and organs, in which a physiological or pathophysiological role of histamine has been considered, no or very few data are known about their histamine content.

This is specially true for human tissues: histamine concentrations have been determined mostly only in single, relatively few organs, such as salivary glands, stomach, liver, lungs, kidney, thyroid gland, uterus, skin, nervous tissue, and mastocytoma (for a survey of the results of 64 authors see Lorenz and Werle, 1974). A comparison of the histamine contents of more than four organs can be read only in the publications of Stone, Merill, and Menechy (1955), Dunér and Pernow (I 960), Lorenz, Pfleger, and Werle (1967), Kumar and others (1968), Anton and Sayre (1969), and Lorenz, Benesch, and others (I970), and only Kumar and others (1968) measured histamine in a greater number of individuals ( $n$ $=68$ ). Thus, we were eager partly to close the gaps in our knowledge about the distribution of histamine in man.

As far as we have found in the literature, nothing has been published until now about the histamine concentrations of tissues from the miniature pig and Mastomys natalensis. Since these two species are used more and more in animal experiments, it seemed significant to obtain data about the distribution of histamine in these animals.

In organs or tissues in which phamacological actions of histamine were observed, the endogenous histamine concentration was considered to be important-besides other parameters-for the evaluation of physiological or pathophysiological functions of histamine. Pharmacological effects of histamine with possible physiological relevance were investigated in man, especially in the gastric mucosa (Code, 1956; Lorenz and Pfleger, 1968), the gastric muscles (Bennett and Whitney, I g66), the intestinal muscles (Bennett, 1965), and the ureter (Borgstedt and others, 1962). Such effects of histamine in other mammals can be read in numerous reviews and books on histamine (e.g., Rocha e Silva, I966). Quite recently Reite (1972) compiled the literature about the pharmacological actions of histamine in animals lower than mammals. Some of these effects, which started our investigations of the histamine contents in the corresponding tissues, are shown in Table $X I V$.

Since histamine was found in sufficient amounts in all these organs (see Results), on principle a physiological role of histamine in these organs cannot be excluded. Thus, our findings may stimulate further investigations on the acceptance or rejection of these hypotheses.

3. The species variability relating to the distribution and localization of histamine in tissues is much greater than has been assumed until now. The results of this publication confirm those of histochemical studies (Hàkanson and others, I970) and of a comprehensive review (Lorenz and Werle, 1974). There was no tissue or organ in animals which showed an absolutely or relatively high or low histamine content in all species investigated.

Gastric mucosa: Even the gastric mucosa, in which a relatively high histamine concentration was regularly demonstrated, contained only medium concentrations in sheep and Mastomys. All other tissues in vertebrates showed much greater species variability than the gastric mucosa. 


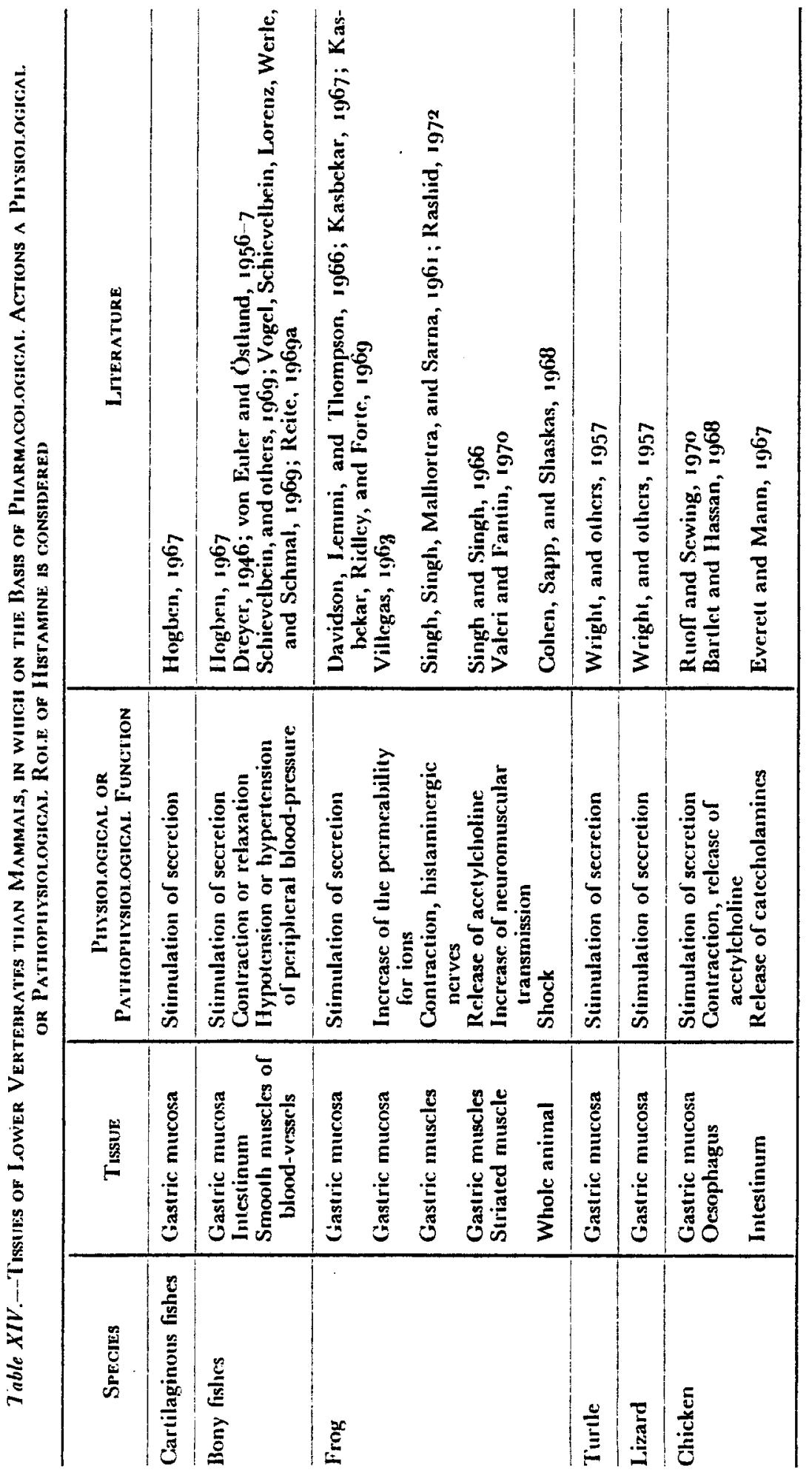


Small intestinum: The small intestinum had a relatively high histamine concentration in man, dogs, foxes, pigs, cattle, guinea-pigs, chickens, ducks, geese, and cartilaginous fishes with the exception of the dogfish. rodents, birds, bonv fishes, and three species of the cartilaginous fishes.

Lungs: The histamine content of the lungs was found to be high in all mammals with the exception of the rat (Rattus rattus) and

Table XV.-Phyla in the Antmal Kingdom, in the Spectes of which Histamine has been Detected

\begin{tabular}{|c|c|c|}
\hline No. & PhYLUM & LITERATURE \\
\hline I & Sponges (Porifera) & $\begin{array}{l}\text { Ungar and others, 1937; Ackermann and List, 1957; Mettrick } \\
\text { and Telford, 1965; Das, Lim, and Teh, } 1971\end{array}$ \\
\hline 2 & Coelenterates (Coelenterata) & $\begin{array}{l}\text { Ungar and others, I937; Mathias, Ross, and Schachter, I958. } \\
\text { I960; Mettrick and Telford, 1965 }\end{array}$ \\
\hline 3 & Flatworms (Plathelminthes) & Mettrick and Telford, 1965 \\
\hline 4 & Roundworms (Aschelminthes) & Mettrick and Telford, 1965 \\
\hline $\begin{array}{l}5 \\
6\end{array}$ & $\begin{array}{l}\text { Segmented worms (Annelida) } \\
\text { Joint-footed animals }\end{array}$ & Ungar and others, 1937; Mettrick and Telford, 1965 \\
\hline & (Arthropoda) & $\begin{array}{l}\text { Ungar and others, 1937; Werle and Gleissner, 1951; Eckert. } \\
\text { Paasonen, and Vartainen, I951; Jaques and Schachter, } \\
\text { 1954; Kerkut and Price, I961; Bhoola, Calle, and Schachter, } \\
\text { 1961; Parsons, 1962; Bertaccini, Neviani, and Roseghini, } \\
\text { 1965; Mettrick and Telford, I965 }\end{array}$ \\
\hline 7 & Molluscs (Mollusca) & $\begin{array}{l}\text { Ungar and others, } 1937 ; \text { Erspamer and Boretti, 1951; } \\
\text { Bertaccini, 1961; Mettrick and Telford, 1965; Huggins and } \\
\text { Woodruff, I } 968 ; \text { Roseghini and Ramorino, 1970 }\end{array}$ \\
\hline $\begin{array}{l}8 \\
9\end{array}$ & $\begin{array}{l}\text { Echinoderms (Echinodermata) } \\
\text { Chordates (Chordata) }\end{array}$ & Ungar and others, 1937; Mettrick and Telford, 1965 \\
\hline $9 \cdot 1$ & Tunicates (Tunicata) & $\begin{array}{l}\text { Mettrick and Telford, 1965; Lorenz and others, 1969; } \\
\text { Lorenz, } 1969\end{array}$ \\
\hline $\begin{array}{l}9.2 \\
0.3\end{array}$ & $\begin{array}{l}\text { Lancelets (Cephalochordata) } \\
\text { Vertebrates (Vertebrata) }\end{array}$ & This paper \\
\hline $\begin{array}{l}9 \cdot 3 \\
9 \cdot 3 \cdot 1\end{array}$ & $\begin{array}{l}\text { Vertebrates (Vertebrata) } \\
\text { Cyciostomes (Cvclostomata) }\end{array}$ & Reite, 1969a, b; Holstein, 1970 \\
\hline $9 \cdot 3 \cdot 2$ & $\begin{array}{l}\text { Cartilaginous fishes } \\
\text { (Chondrichthyes) }\end{array}$ & $\begin{array}{l}\text { Hogben, } 1967 \text {; Lorenz and others, } 1969 \text {; Lorenz, 1969; Reite, } \\
\text { I } 969 \mathrm{a}, \mathrm{b}\end{array}$ \\
\hline $9 \cdot 3 \cdot 3$ & Bony fishes (Osteichthyes) & $\begin{array}{l}\text { Reite, 1965; Lorenz and others, 1969; Lorenz, 1969; Reite, } \\
1969 \mathrm{a}, \mathrm{b}\end{array}$ \\
\hline $9 \cdot 3 \cdot 4$ & Amphibians (Amphibia) & $\begin{array}{l}\text { Erspamer, Vitali, Roseghini, and Cei, 1963, 1964; Erspamer, } \\
\text { Roseghini. and Cei, 1964; Reite, 1965; Davidson and } \\
\text { others, 1966; Cei and others, I967; Takaya and others, } \\
\text { ! } 967 \text {; Lorenz, I969; Lorenz and others, 1969; Reite, 1969a, } \\
\text { b; Erspamer and Cei, 1970; Erspamer, I971 }\end{array}$ \\
\hline $9 \cdot 3 \cdot 5$ & Reptiles (Reptilia) & $\begin{array}{l}\text { Wright and Trethewie, 1956; Lorenz, I969; Lorenz and } \\
\text { others, I969; Reite, 1969a, b; Takava, 1969; Gabe, I971 }\end{array}$ \\
\hline $9 \cdot 3.6$ & Birds (Aves) & $\begin{array}{l}\text { Misrahy, I946; Beaumariage and Lecomte, 1955; Lorenz, } \\
1969 \text {; Lorenz and others, 1969; Takaya, 1969; Ruoff and } \\
\text { Sewing, 1970b }\end{array}$ \\
\hline $9 \cdot 3 \cdot 7$ & Mammals (Mammalia) & A survey with 106 tables, see Lorenz and Werle, 1974 \\
\hline
\end{tabular}

Relatively low histamine contents were measured in sheep, rats, pigeons, tortoises, and in all bony fishes.

Liver: The liver showed high histamine contents in dogs, foxes, and cattle as well as in the Caspian pond turtle and in the gecko. Low values were determined in man, all the Natal rat (Mastomys natalensis). In birds and in one species of the tortoises, the histamine concentrations in the lungs were relatively low.

Kidney: The kidney was considered to be an organ poor in histamine in all mammals and birds. However, in reptiles, in the pike, and 
in Oxynotus centrina, a cartilaginous fish, relatively high histamine contents were detected.

Spleen: The histamine concentration in the spleen showed a considerable scatter from species to species. It was found to be high in birds, reptiles, and rabbits, in all other species medium or low.

Thus, with the exception of the gastric mucosa, there was no uniform tissue preference for the storage of histamine in any of the species investigated. It seems very difficult to correlate the distribution of histamine with a special function of this amine. However, this kind of unequal distribution of histamine in the tissues and species seems to contradict the hypothesis that histamine plays a general role in the body, e.g., as a regulator of ubiquitous metabolic processes (Johnson, 1971) or of the microcirculation (Waton, 197 I).

A correlation between the histamine content and a pharmacological function of histamine can so far be demonstrated only in the gastric mucosa. Histamine stimulates the gastric acid secretion in all mammals so far studied (Code, I956; Lorenz and Pfleger, I968), in birds (Ruoff and Sewing, 1970a), reptiles (Wright, Florey, and Sanders, 1957), amphibia (see Table XIV), as well as in bony and cartilaginous fishes (Hogben, 1967). In all these orders and species, histamine is localized in the gastric mucosa in high, or in two exceprions (sheep, Mastomys) in at least medium concentrations. In those vertebrates, however, which do not have a specific area with gastric glands in the intestinal tract, such as the stomachless bony fishes (carp, Rutilus rutilus, Labrus berggyltra) and the cyclostome Myxine glutinosa (Reite $1969 b$, and this paper), only a very low histamine concentration can be found in the whole gut. Also in molluscs and crustaceans, in which the stomach has no digestive functions, only a low histamine concentration was measured in gastric tissues, whereas the liver, the common digestive gland of these animals, was rela. tively rich in histamine.

The correlation between the histamine content and the pharmacological action of histamine in the gastric mucosa is naturally no evidence for the hypothesis that histamine may be a physiological stimulator of the gastric acid secretion. On the other hand, it is again consistent with the view that histamine plays a specific role in the secreting stomach and not an unspecific one (Johnson, I971; Waton, I971), as already mentioned. The activation of the adenyl cyclase, for instance, may be considered as such a physiological function of histamine (Nakajima, Hirschowitz, and Sachs, 197I).

4. Important hints for a physiological role of histamine in the animal kingdom should be expected from phylogenetic and evolutionary studies. The occurrence of histamine has been demonstrated until now in numerous phyla and orders of animals (Table $X V$ ). Phylogenetic investigations on the concentration of histamine in tissues were performed with relatively few species or with one tissue alone, such as the skin or the gastric mucosa, by Ungar and others (1937), Mettrick and Telford (1965), by Erspamer's group (e.g., Cei, Erspamer, and Roseghini, 1967), by Reite (1969a, b), Lorenz (1969), Lorenz and others ( 1969$)$, and Takaya (1969). A comparison of the histamine contents of numerous tissues and organs in many species, orders, and phyla is now possible from the data presented in this publication.

There are, however, also few evolutionary and phylogenetic studies on the pharmacological actions of histamine on the smooth muscles in the gut and on the circulation (Dreyer, 1946; von Euler and Ostlund, 1956-7; Reite, 1969a; Schievelbein, Vogel, Lorenz, and Schmal, 1969 ) as well as on the gastric secretion (Hogben, 1967). By these authors it was shown that histamine is practically inactive on the smooth muscles and on the circulation of cartilaginous fishes and also many bony fishes, but not on the gastric secretion. These findings seem to be again an argument for a specific function of histamine in the gastric mucosa of the chordates.

As far as we know, only two authors performed phylogenetic studies on the localization of histamine in certain cells (Reite, I 965 ; Takaya, Tsuneo, and Endo, 1967; Takaya, 1969). It seems very remarkable that in fishes and Amphibia histamine is not stored in mast cells. In the evolution, beginning 
with reptiles and birds, histamine could be demonstrated in these cells, which are quantitatively the most important stores of histamine in mammals (Riley and West, 1953).

Unlike the findings in most of the mammals (Håkanson and others, 1970), histamine in the gastro-intestinal tract of other classes of vertebrates is therefore called 'non-mast cell histamine'.

\section{REFERENCES}

AckermanN, D., and List, P. H. (1957), 'Über das Vorkommen beträchtlicher Mengen Histamin in der niederen Tierwelt', Hoppe-Seyler's Z. physiol. Chem., 308, 274-276.

ANTON, A. H., and SAYRe, O. F. (1969), 'A modified fluorometric procedure for tissue histamine and its distribution in various animals', $\mathcal{F}$. Pharmac. exp. Ther., 166, 285-292.

Aures, D., Davidson, W. D., and Hakanson, R. (1969), 'Histidine decarboxvlase in gastric mucosa of various mammals ', Eur. $\mathcal{J}$. Pharmac., 8, 100-106.

Barsoum, G. S., and Gaddum, J. H. (1935), 'The pharmacological estimation of adenosine and histamine in blood ', $\vec{f}$. Physiol., Lond., $85,1-13$.

Bartzet, A. L., and Hassan, T. (1968)," Some actions of histamine and 5-hydroxytryptamine on isolated chicken oesophagus ', Br. F. Pharmac., 32, $156-163$.

BeAtMaRLage, M. L., and Lecomte, J. (1955), - Teneur en histamine de quelques organes du coq ', C.r. Seanc. Biol., 149, 227-229.

BENNETT, A. (1965), 'A pharmacological investigation of human isolated ileum', Nature, Lond., 208, 1289-1291.

BENNETT, A., and WhITNEY, B. (I 966 ), 'A pharmacological investigation of human isolated stomach ', Br. J. Pharmac., 27, 286-298.

BerTACCIN, G. (1961). Discussion to H. $H$. Adam. Histamine in the central nervous system ', Regional Neurochemistry ed. Kety and Elkes), p. 305. Oxford: Pergamon.

Bertaccini, G., Neviani, D. E., and Roseghin. M. (1965), 'Occurrence of biogenic amines and other active substances in methanol extracts of beetle (Luciola italica)', $\mathcal{F}$. Insect. Physiol., Ix, 1055-1060.

Best, C. H., Dale, H. H., Dudley, H. W., and THORPE, W. V. (1927), "The nature of the vaso-dilator constituents of certain tissue extracts ', 7. Physiol., Lond., 6a, 397-4!7.

Bhoola, K. D., CALLE, J., and Schachter, M. (196r), 'Identification of acetylcholine, 5hydroxytryptamine, histamine and a new kinin in hornet venom', J. Physiol., Lond., 159, $167^{-1} 74$.

BoRgStedt, H. H., Benjamin, J. A., and EMmel, V. M. (1962), Role of histamine in ureteral function ', $\mathcal{J}$. Pharmac. exp. Ther., $13^{6}, 3^{86-392 .}$
Carlini, E. A., and Green, J. P. (1963), 'The measurement of histamine in brain and its distribution', Biochem. Pharmac.. $12,1448-1449$.

Cei, J. M., Erspamer, V.. and Roseghini, MI. (I967), 'Taxonomic and evolutionary significance of biogenic amines and polypeptides occuring in amphibian skin. I. Neotropical leptodactvlid trogs', System. Zool., 16, 328-372.

CODE, C. F. (1956), 'Histamine and gastric secretion ', Ciba Found. Symp. on Histamine, pp. 189-219. London: Churchill.

COHEN, S. G., SAPP, T. M., and ShasKas, J. R. (1968), 'Histamine shock in the frog', Am. $\mathcal{J}$. Physiol., 214, 1288-129o.

DAs, N. P.. LIM, H. S., and TEH, Y. F. (1971), - Histamine and histamine-like substances in the marine sponge, Suberites inconstans', Comp. gen. Pharmac., 2, 473-425.

Davidson, W. D., LEMm, C. A. E., and Thompson, J. C. (1966), 'Action of gastrin on the isolated gastric mucosa of the bullfrog ', Proc. Soc. exp. Biol. Med., 12x, 545-547.

DREYER, N. B. (1946), "Histamine and posterior pituitary actions on elasmobranch and teleost smooth muscle', Archs int. Pharmacodyn. Ther., $72,440-443$.

DeNER, H., and Pernow, B. (1960). 'Histamine in man under physiological and pathological conditions'. Acta med. scand., r6B, 307-323.

Eckert, D., PaAsonen, M., and Vartainen, A. (195I), 'On histamine in the gnat (Culex pipiens) ', Acto pharmac. toxic., 7, 16-22.

Ellenberger, W., and Baum, H. (I912), Handbuch der vergleichenden Anatomie der Haustiere. Berlin: Hirschwald.

ERSPAMER, V. (1971), ' Biogenic amines and active polypeptides of the amphibian skin', A. Rev. Pharmac., xx, 327-350.

ERSPAMER, V., and BoretTI, G. (1951), 'Identification and characterization by paper chromatography, of enteramine, octopamine, tyramine, histamine and allied substances in extracts of posterior salivary glands of octopoda and in other tissue extracts of vertebrates and invertebrates', Archs int. Pharmacodyn. Ther., 88, 296-312.

ERspamer, G. F., and Ceir, J. M. (1970), ' Biogenic amines and active polvpeptides in the skin of Leptodactylus vilarsi melin', Biochem. Pharmac., I9, $321-325$.

ERspamer, V., Roseghin, M., and Cei, J. M. ( 1964$)$, Indole-imidazole- and phenyl-alkylamines in the skin of thirteen leptodactylus species ', Biochem. Pharmac., 13, 1083-1093.

ERspamer, V., VtTal, T., Roseghint, M., and CEI, J. M. (1963), "Occurrence of new imidazole alkylamines (spinaceamine and 6-methylspinacaemine) in skin extracts of Leptodactylus pentadactylus labyrinthicus', Experientia, 19, 346347.

ERspamer, V., Vitall, T., Roseghin, M., and CEI, M. J. (1964), The identification of new 
histamine derivates in the skin of Leptodactylus'. Archs Biochem. Biophys., 105, 620-629.

von EuLer, U. S., and OstLund, E. (1956-7), - Effects of certain biologically occurring substances on the isolated intestine of fish , Acta physiol. scand., 38, 364-372.

EveretT, S. D., and ManN, S. P. (1967), 'Catecholamine release br histamine from the isolated intestine of the chick ', Eur. 7. Pharmac., I, 310-320.

Gabe, M. (I97I), 'Repartition des cellules histaminergiques dans la paroi gastrique de quelques reptiles', C. r. hebd. Séanc. Acad. Sci., 273, 2287-2289.

GugGeNHEIM, M., and LöFFLER, W. (1916), - Biologischer Nachweis proteinogener Amine in Organextrakten und Körperflüssigkeiten', Biachem. Z., 72, 303-311.

Hakanson, R., Owman, Ch., Sjöbero, N-O., and SPORRONG, B. (1970), 'Amine mechanisms in enterochromaffin and enterochromaffinlike cells of gastric mucosa in various mammals', Histochemistry, 21, 189-2 I0.

Hogben, C. A. M. (1967), 'Response of the isolated dog fish gastric mucosa to histamine', Proc. Soc. exp. Biol. Med., 124, 890-893.

Holsters, B. (1970), 'Metabolism of subeutaneously injected "C-histamine in Myxine glutinosa', Acta physiol. scand., 80, 433-437.

Hugcins, A. K., and Woodrupf, G. N. (I g68), 'Histamine metabolism in invertebrates ', Comp. Biochom. Physiol., 26, 1107-1 I II.

JaQUES, R., and Schachter, M. (1954), "The presence of histamine, 5-hydroxytr)ptamine and a potent, slow contracting substance in wasp venom ', Br. 7. Pharmac., 9, 53-61.

Jotnson, L. R. (1971), "Control of gastric secretion: no room for histamine?', Gastroenterolog, 6r, 106-1 18 .

Kasbekar, D. K. (1967), 'Studies of resting isolated frog gastric mucosa', Proc. Soc. exp. Biol. Med., 125, 267-277.

Kasbekar, D. K., Rimley, H. A. and Forte, J. G. (1969), "Pentagastrin and acerylcholine relation to histamine in $\mathrm{H}^{+}$secretion by gastric mucosa', Am. J. Physiol., 216, 961-965.

Kraxur, G. A., and Price, M. A. (1961), 'Histamine content of tissues from the crab Carcinus maenas', Comp. Biochem. Physiol., 3, 315-377.

Koch, T. (I 970), Lahrbuch der Veterinär-Anatomie, vol. 1-3. Jena: Fischer.

Kremzner, L. T., and Pfeiffer, C. C. (ig66), 'Identification of substances interfering with the fluorometric determination of brain histamine', Biochem. Pharmac., 15, 197-200.

Kürenthal, W., Matthes, E., and Renner. M. (1967), Leitfaden für das Zoologische Praktikum. Stuttgart: Fischer.

Kumar, V., LADDU, A. R., LAHIRI, P. K., and Savyal, R. K. (1968). The physiological levels of histamine in human tissues' Int. Archs Allergy, 34, 233-236.
LORENz, W'. ( I 969), 'Lokalisation, Stoffwechsel und Fragen einer physiologischen Funktion von Histamin in Speicheldrüsen, Schilddriise und Magen', Thesis, University of Munich.

Lorenz, W., Barth, H., Küche, J., RemanN, H. J., Schmal, A., Matejka, E. Mathlas, Ch., Hutzel, M., and Werle, E. (197I), 'Histamine in the pig: determination, distribution. release and pharmacological actions', Eur. 7 . Pharmac., 14, $155^{-175}$.

Lorenz, W., Barth. H., and Werle, E. (1970), 'Histamine and histamine methyltransferase in the gastric mucosa of man, pig, dog and cow', Naunyn-Schmiedebergs Arch. Pharmak. exp. Path., 267, $421-432$.

Lorenz, W., Benesch, L., Barth. H., Matejks, E., Meyer, R., Kusche, J., Hutzel, M., and WERLE, E. (1970) ' Fluorometric assay of histamine in tissues and body fluids. Choice of the purification procedure and identification in the nanogram range ', $Z$. analyt. Chem., 252, 94-98.

Lorenz, W., Doenicke, A., Meyer, R., Reimann, H. J., Kusche, J., Barth, H., Gersing. H., Hutzel, M., and Weissenbacher, B. (1972), - Histamine release in man by propanidid and thiopentone: pharmacological effects and clinical consequences', Br. $\mathcal{F}$. Anaesth., 44, 355-370.

LoRenz, W., HuHnd, A., Kusche, J., BARTH, H., Haubensak, G., Hutzer, M., Schmal, A., Gerant, M., Wächter, A., Matejka, E., HAhN, H., and WerLe, E. (1973). 'Histamine and salivary secretion'. $X X V$. Int. Cong. physiol. Sci., Lodź (ed. Mašlinski), in the press.

Lorenz, W., and Prleger, K.' (1968), 'Stoffwechsel und physiologische Funktion von Histamin im Magen', Klin. Wischr., 46, 57-71.

LORENz, W., PFLEGER, K., and WERLE, E. (196\%), "Fistamin und Histidindecarboxylasen im oberen Verdauungstrakt von Mensch, Hund, Meerschweinchen und Ratte ', Naunyn-Schmiedebergs' Arch. Pharmak. exp. Path., 258, 150-159.

Lorenz, W., Remann, H. J., Barth, H., Kusche, J., Meyer, R., Doenicke, A., and Hutzel, M. ( 1972$)$, 'A sensitive and specific method for the determination of histamine in human whole blood and plasma', Hoppe-Soler's Z. physiol. Chem., 353, 9 I I -920.

Lorenz, W., Schater, A., Hertimand, St., Matejra, E., and WerLe, E. (1969), 'Biochemical and histochemical studies on histamine in the digestive tract: distribution in different chordates and cellular stores in the dog', Naunyn-Schmiedebergs Arch. Pharmak. exp. Path., $264,274$.

LoRenz, W', Schmal, A., Remann, H. J., Tauber, R., Uhlig, R., MaNx, G., Barth. H., Kusche, J., Seidel, W., Doenicke, A., HamelMANN, H., and Werle, E. (1972), 'Histamine release in man, dog and pig: problems of its determination and evaluation under various pharmacological and clinical conditions ', Ist $A$. 
Meet. Eur. Branch Histamine Club, Paris 1972, J. Pharmac. (Paris), 3, 526.

LORE.vz, $W$. and WerLe, E. (1974). Occurrence. distribution and subcellular localization of histamine in man, animals and plants', in International Encyclopedia of Pharmacology and Therapeutics (ed. Maxwell), section 74. Oxford: Pergamon. (In the press.)

Macintosh, F. C., and Paton, W. D. M. (1949), - The liberation of histamine by certain organic bases ', J. Physiol., Lond., rog, i g0-21 9.

Mathias, A. P., Ross, D. M., and Schachter. M. (1958), 'Distribution of histamine, j-hydroxytryptamine, tetramethylammonium, and other substances in coelenterates possessing nematocysts ', J. Physiol., Lond., I42, 56 P-57P.

Mathias, A. P., Ross, D. M., and Schachter, M. (1960), The distribution of 5 -hydroxytryptamine, tetramethylammonium, homarine. and other substances in sea anemones ; $\mathcal{J}$. Physiol., Lond., 151, 296-311.

MetTrick. D. F., and Telford, J. M. (g65). 'The histamine content and histidine decarboxylase activity of some marine and terrestrial animals from the West Indies', Comp. Biochem. Physiol., 16, 547-j59.

Michielson, I. A., and Cofrman, P. Z. $(1967)$, 'Histamine and spermidine in tissues of the guinea-pig ': Biochem. Pharmac., 16, 1636-1671.

MisRafy, G. A. (1946), 'The metabolism of histamine and adenvlic compounds in the embrvo', Am. J. Physiol., 147, 462-470.

NAKajma, S., Hirschowttz, B. I., and Sachs, G. (1971), "Studies on adenvl-cyclase in Necturis gastric mucosa', Archs Biochem. Biophys., 143, 123-126.

Parsons, J. (I 962), 'Pharmacology of the poison gland of the locust, Poekilocerus bufonius Klug ', Proc. ent. Soc., 27, $21-22$.

Rushid. S. (1972), The nature of the parasvmpathetic nerve fibres of the stomach of Rana temporaria', Archs int. Pharmacodyn. Ther., 195, 247-251.

REITE, O. B. (1965). 'A phvlogenetical approach to the functional significance of tissue mast cell histamine', Vature, Lond., 206, 13341335.

REITE, O. B. (I969a), "The evolution of vascular smooth muscle responses to histamine and 5 hydroxytryptamine. I. Occurrence of stimulatory actions in fish', Acta physial. scand., 75, $221-239$.

REITE, O. B. (196gb), ' Phylogenetical persistance of the non-mast cell histamine stores in the digestive tract: a comparison with mast cell histamine ', Experientia, 25, 276-277.

RerTE, O. B. (1972), ' Comparative physiology of histamine ', Physiol. Rev., 52, 778-805.

Rerte, O. B., and Davts, W. H. (1970), 'Mast ceils and hibernation: observations in the Indiana bat, Mlyotis sodalis', Experientia, 26, $745-746$.
RILEY, J. F., and West, G. B. (1953), 'The presence of histamine in tissue mast cells ', $\mathcal{J}$. Physiol., Lond., 120, 528-537.

Rocha E Stlva, M. (1966), "Histamine and antihistaminies'. in Handbook of Experimentai Pharmacology (ed. Eichler and Farah), vol. i 8, p. I. Heidelberg: Springer.

Roseghin, MI., and Ramorino, L. M. (1970), jHydroxytryptamine, histamine and $\mathrm{N}$-acetylhistamine in the nervous system of Dosidicus gigas', $f$. Neurachem., 17, 489-492.

Ruofr, H. J., and Sewing, K. Fr. (1970a), 'Die Wirkung von Histamin, Carbachol, Pentagastrin und Hühnergastrinextrakten auf die Magensekretion von nicht-narkotisierten Hühnern mit Magenfistel', Vaunyn-Schmiedebergs Arch. Pharmak. exp. Path., 267, I 70-1 76.

Ruofr, H. J., and Sewing, K. FR. (1970b), 'Histamin, Histidindecarboxylase und Gastrin im oberen Verdauungstrakt des Huhns', Vaunyn-Schmiedebergs Arch. Pharmak. exp. Path., $265,301-309$.

SCHAYER, R. W. (1964), ' Histamine and hyperaemia of muscular exercise ', Nature, Lond., 201, 195-196.

Schinvelbein, H., Vogel, R., Lorenz, W., and Schmal, A. (1969), "Contributions to the evolution of blood pressure regulation ', Z. klir. Chem. klin. Biochem., 7, 461-465.

Seidel, W., Lorenz, W., Doentcke, A., Mani, G., and UHLIG, R. (1973), 'Histaminfreisetzung beim Menschen und StreBulcuspathogenese ', Z. Gastroenterologie, 11, 297-300.

Shore, P. A., Burkhalter, A., and Cohn, V. H., jun. (1959), 'A method for the fluorometric assay of histamine in tissues', 7 . Pharmac. exp. Ther.. 127, 182-186.

Singh, I., and Singh, S. I. (1966), 'Histaminergic transmission in a frog vagus stomach muscle preparation', Archs int. Physiol. Biochem., 74, 365-373.

Singh, I., Singh, S. I., Malhortra, C. L., and SARNA, T. I. (196I), 'Release of j-hydroxytryptamine on stimulation of nerves to frog's stomach muscle and its significance ', Archs int. Pharmacodyn. Ther., 134, 131-147.

StONe, I. L., Merill, I. M., and Menechy, G. R. (1955), Distribution of histamine in human tissues'. Fedn Proc. Fedn Am. Socs exp. Biol. 14, 147.

StORER, T. J., and Lisinger, R. L. (1965), General Zoology, $4^{\text {th }}$ ed. New York: McGraw-Hill.

TAKAYA, K. (1969), 'The relationship between mast celis and histamine in phylogeny with special reference to reptiles and birds', Arch. histol. japan., 30, $40 \mathrm{I}-420$.

TAKAYA, K., TsuNeo, F., and ENDO, K. (1967), - Mlast cells free of histamine in Rana catesbiuna, Nature, Lond., 215, 776-777.

L'NGar, G., Ungar, A., and Parrot, J. L. (1937), - Sur la presence de substances histaminiques dans les tissus des invertébrés marins', $C . r$. Séanc. Soc. biol., 120, I $156-1159$. 
Valer, V. C., and Fantin, G. P. (1970), 'Influenza dell'istamina sulla risposta del fuso neuromuscolare divand', Boll. Soc. ital. Biol. sper., 46, 553-554.

VILLEGAS, L. (1963). 'Action of histamine on the permeability of the frog gastric mucosa to potassium and water ', Biochim. biophys. Acta, 73, $377-385$.

VoGel, R., SchIEvelbeIN, H., LORENz, W.. Wierle, E., and Schmal, A. (1969), 'Contributions to the evolution of blood pressure regulation, Part II', Z. klin. Chem. klin. Biochem., 7, $464-468$.

Waton, N. G. (1971), ' Histamine and the parietal cell ', Am. F. dig. Dis., 16, $921-938$.

WerLe, E., and Gi.eIsSNer, R. (1951) ' Uber die Herkunft des Histamins der Bienen', $\mathbf{Z}$. Vitam.-, Horm.- u. Fermentforsch. 4, 450-457.
WerLe, E., and LORENz, W. (1970), 'The antikinin action of some antihistaminic drugs on the isolated guinea-pig ileum, rat uterus and blood pressure of the anesthetized dog'. Int. Symp. on Bradykinin and Related Substances. Fiesole. Adv. exp. Biol. Med., 8, 447-453. New York: Plenum.

WRIGHT, R. D., FlorEY, H. W., and SANDERS, A. G. (1957), "Observations on the gastric mucosa of reptilia', Q.J. exp. Physiol., 42, 1-i 4. WRIGHT R. D., and TREThEWIE, E. R. (1956), 'Histamine of the reptilian stomach and lung', Nature, Lond., 178, 546-545.

WURMBACH, H. (1971), Lehrbuch der Zoologie, vol. II. Stuttgart: Fischer.

Key Word Index: Histamine, specific determination, man, chordates, echinoderms, molluscs, crustaceans. 